an old 'people's luncheon club suffered from diarrhoea 12 hours after eating a meal consisting of steak and kidney, potatoes, cabbage, and gravy. $\mathrm{Cl}$. welchii was isolated from the faeces of four affected persons and from steak and kidney in a specimen meal $\left(1.1 \times 10^{7} / \mathrm{g}\right)$.

\section{Outbreak 3}

During July 1976,77 patients in a geriatric hospital experienced diarrhoea 12-15 hours after consuming reheated roast beef. $\mathrm{Cl}$. welchii was isolated from 68 of the patients and from the roast beef $(1.5 \times$ $10^{5} / \mathrm{g}$ ).

In all three outbreaks the strains isolated were lecithinase-negative on nutrient egg yolk medium. All strains had identical serological typing reactions (Hughes et al., 1976) agglutinating with the unusual combination of four antisera, types 25,27 , 31 , and 68 . The three outbreaks occurred within 25 miles of each other and a common source of the organism is possible.

Representative strains from the three outbreaks were examined at the Wellcome Research Laboratories for the production of toxins. A very weak alpha toxin was produced which exhibited a very weak $a$-haemolytic activity but no demonstrable lecithinase activity. With these strains, therefore, the haemolytic test is more sensitive than the lecithinase test for detecting alpha toxin. The strains were considered to be atypical $\mathrm{Cl}$. welchii type A. A strain from one of the outbreaks has been deposited with the National Collection of Type Cultures (reference number NCTC 11144).

The implication of these results is clear. If laboratories are relying on the production of lecithinase as the sole confirmatory test for $\mathrm{Cl}$. welchii then it is possible that some strains will be missed. It is recommended, therefore, that organisms that are lecithinase-negative but which grow well and colonially resemble $C l$. welchii on neomycin blood agar should be tested for motility, gelatin hydrolysis, nitrate reduction, action on litmus milk, and fermentation of glucose, lactose, sucrose, salicin, maltose, and starch.

We are unaware of any previous reports of outbreaks of $\mathrm{Cl}$. welchii food poisoning where the cultures isolated were lecithinase negative and would be interested to hear whether other workers have encountered a similar problem.

We are grateful to Dr P. D. Walker and Mrs G. Roper of the Wellcome Research Laboratories for their help.
J. A. PINEGAR and M. F. STRINGER

Public Health Laboratory, Bridle Path, York Road, Leeds, LS15 7TR and Food Hygiene Laboratory, Central Public Health Laboratory, Colindale Avenue, London NW9 5 HT

References

Hayward, N. J. (1943). The rapid identification of $\mathrm{Cl}$. welchii by Nagler tests in plate cultures. Journal of Pathology and Bacteriology, 55, 285-293.

Hughes, J. A., Turnbull, P. C. B., and Stringer, M. F. (1976). A serotyping system for Clostridium welchii ( $C$. perfringens) type $\mathrm{A}$, and studies on the type specific antigens. Journal of Medical Microbiology, 9, 475-486.

McClung, L. S. and Toabe, R. (1947). The egg yolk plate reaction for the presumptive diagnosis of $\mathrm{Cl}$. sporogenes and certain species of the gangrene and botulinum groups. Journal of Bacteriology, 53, 139-147.

Nagler, F. P. O. (1939). Observations on a reaction between the lethal toxin of $\mathrm{Cl}$. welchii (type A) and human serum. British Journal of Experimental Pathology, 20, 473-485.

\section{Book reviews}

Cerebrospinal Fluid Cytology. An Intro duction and Atlas. By Manfred Oehmichen? Pp. vii + 208; illustrated; £27.75. Philadelphia, London, Toronto: W. BS Saunders. 1976.

Many of us can remember when the cerebrospinal fluid (CSF) contained onlP three kinds of cell, and even these could be difficult to identify in the counting chamber. Until the introduction of Sayk's sedimentation method about 19 years ago, only very dedicated clinicats pathologists succeeded in making satisis factory smears from fluids with low ceit counts. Anybody can do it now, eithero with a sedimentation chamber or with it요 successor, the cytocentrifuge. Most of the. numerous publications on this subject are in German and have been largely ignore by workers in America and, I am afraid, in Britain.

Oehmichen's book shows many photographs in half-tone and in colour, mainlog from sediment-chamber preparations; bu it is not just a picture-book. The text discusses the pathophysiology of the celp and their origins and functions from studies performed in large part by the author. Far from being an introduction as the subtitle states, it covers pretty we all that is known at present about the cells of CSF.

There are a few cell identifications about which I feel doubtful. The 'mast cells' in Plate 2 look very unlike the usual tissue mast cells and would pass more easily for promyelocytes. The statement that meduty loblastoma cells are almost indis tinguishable from lymphoma cells is wrong, because the former nearly always occur in coherent clusters, the latters never. One would also like some evidence that the cells represented as those $\overline{96}$ oligodendroglioma and pinealoma afe really tumour cells and not reactive lymphoid cells.

In the next edition a revision of thfe text could remove a number of awkware nesses resulting from the translatof difficulty in rendering medical German into medical English; but these do not interfere with comprehension.

Advances in knowledge of cell functiō (particularly of the lymphoctyes an macrophages) will make future editio of this book progressively more importanf. With its exhaustive and up-to-dare bibliography and thorough index it 
recommended both to researchers and to those engaged in the routine analysis of CSF.

A. I. SPRIGGS

Light Microscopic Techniques in Biology and Medicine. By J. James. (Pp. xi + 336; illustrated; Dfl. $90 ; £ 21.60$.) The Hague: Martinus Nijhoff B.V. 1976.

This book sets out to give enough background optics for a rational approach to all the common microscopic techniques as well as the basic principles of less common ones and on the whole it succeeds admirably. The author does not claim to have written a comprehensive treatise but has given a good guide for further reading at the end of each chapter. There are excellent line drawings which render the basic optics intelligible with minimal mathematical expertise. Surprisingly, one or two of the photomicrographs are disappointing. This is also a very practical work and even includes a section on posture which will be welcomed by sufferers of cervical spondylosis.

On the whole the English is clear and very readable though occasionally it has a slightly stilted Germanic flavour. There are a few typographical errors of minor importance though the one on p. 195, fourth line from the bottom where 'anisotropic' should read 'isotropic' is more serious. These small criticisms do not, however, detract from the value of this well-printed and well-presented book. I fear, however, that few will be able to afford to add it to their personal collection. Nevertheless it would be a valuable addition to the laboratory library for the profit of technician and pathologist, both of whom are regrettably often woefully ignorant of the workings of this basic laboratory tool.

\section{J. C. VALENTINE}

Hepatocellular Carcinoma. Edited by K. Okuda and R. L. Peters. (Pp. $x+499$; illustrated; £27.00.) Chichester: John Wiley. 1976.

Although relatively uncommon in the western world, hepatocellular carcinoma has attracted much attention for a number of reasons. These included the association with and the possible aetiological role of aflatoxin food contamination, oral contraception, hepatitis B infection, and genetic factors; the significance of hepatocyte dysplasia as a pre-neoplastic lesion; the inappropriate secretion of humoral substances and alpha feto-protein and their value in diagnosis; the development of isotope scanning and angiography in localization; and the recent attempts at radical cure by surgical resection and chemotherapy. These are among the many topics dealt with in detail in this book. For the clinical pathologist it would be difficult to imagine a more complete and lavishly illustrated account not only of primary liver cancer, but of all other human hepatic tumours and tumourlike lesions, both benign and malignant.

Each of the 21 chapters stands as a review article by one or two acknowledged experts. While this has led to some unevenness in overall presentation and in relevance for the general reader there is little by way of overlap or conflicting statements, and the book can be recommended with confidence to all clinicians and pathologists concerned with human liver disease. It appears that this is the first of a series on diseases of the liver from this publishing house, and one looks forward with interest to subsequent volumes.

\section{R. S. PATRICK}

The Cervix. Edited by J. A. Jordan and Albert Singer. (Pp. xviii +529 ; illustrated; $£ 20.00$.) London: W. B. Saunders. 1976.

This book comprises 43 chapters by as many different contributors. The sheer size of the book bears testimony to the extent of the participation of the human cervix in the advance of biological knowledge which has occurred in the last two decades.

A comprehensive coverage of most physiological and pathological conditions affecting the cervix is presented, and considerable attention is paid to new fields of research. In the main, the discussion is critical and well balanced, and most of the numerous illustrations are of a high quality. The description and correlation of colposcopic and histopathological patterns in cervical epithelial dysplasia together with transmission and scanning electron microscopy of normal and abnormal epithelium is most welcome. The uterine cervix is presented, quite correctly, as a dynamic structure rather than one merely fulfilling a passive role in reproduction.

This book is a reference work which is largely directed towards specialists in the field of reproductive and gynaecological disorders. The content is instructive and valuable and should appeal to both clinician and scientist alike.

J. O. W. BEILBY

Developmental Biology and Pathology. Current Topies in Pathology. Vol. 62. Edited by $A$. Gropp and K. Benirschke. (Pp. ix +218 ; illustrated; $\$ 39 \cdot 40$.) Berlin: Heidelberg:New York:Springer-Verlag. 1976. ڤ్లు

This book is part of a long running series. in which various topics are reviewed by $\vec{A}$ workers active in their particular fields of study. It has always maintained a high scientific standard, and the present volume? is no exception. After a brief introduction. by Austin on errors of very early develop-ir ment, 12 topics are dealt with under the four general headings of Oocyte Maturation, Early Embryo and Maternal Host,o Pharmacological and Hormonal Factors. in Early Embryogenesis, Teratology, and Cytogenetics. Much of the information will be useful to paediatric or gynaecological pathologists, particularly those who wish to acquire some knowledge of the background against which many of the disease processes that concern them are expressed. Illustrations and diagrams are of high quality throughout, anch references are up to date. Although the symposium on which this book was尺 based was held in 1974, many 1975 and 1976 references are included.

C. L. BERRY?

The Neutrophil. By Patrick Murphy (Pp. xii + 217; illustrated; $\$ 21 \cdot 54$. Plenum, New York and London: PlenumoMedical Book Company. 1976.

Although the neutrophil is not so fashionable a cell as the lymphocyte, there are quite a lot of people working with neutro-? phils nowadays. It is possible to hold international conferences on topics such as chemotaxis or bactericidal mechanisms and to fill a room with experts who disagree about quite a lot of things $N$ Consequently, to write a monograph entitled The Neutrophil is not a lighto undertaking. Dr Murphy, in setting out on this task, decided, I think rightly, not to attempt to be encyclopaedic butes to hinge his discussion around selected pertinent papers. $\mathrm{He}$ begins at the begin $-\frac{T}{-}$ ning by telling us what the cells look like $\mathrm{He}$ has covered most of the fields of neutrophil physiology that anyone likely to be interested in neutrophils would wish to see dealt with, even fields about which nothing is really known, such as control ob 